\title{
Dimensi Struktural Kemiskinan
}

\author{
Oleh : Sunyoto Usman
}

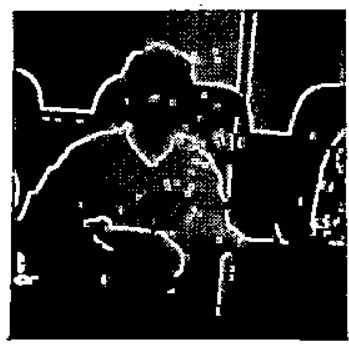

Sunyoto Usman, lahir di Jember 16 Desember 1950. Alimni Fisipol U GM dan Program Doktor diselesaikan di Flinders University, Australia. Selain sebagai dosen tetap pada almamaternyá ia juga sebagai Pengelola Program Studi Sosiologi Pasca Sarjana UGM. Pernah melakukan Penelitian tentang "Kiat Kelompok Miskin Menepis Kemiskinan di Bantul dan Semarang".

\section{Pendahuluan}

Keinginan menanggulangi kemiskinan sebenamya bukan suatu hal baru. Kalau kita simak lagi lembar-lembar PJ̣PT I, disana terlihat bahwa 'menjelang pelaksanaan Repelita Ketiga (1979/1980 1983/1984) yang lalu pemerintah mencanangkan dua pokok kebijaksanaan pembangunan "yaitu: mengurangi jumlah penduduk yang hidup di bawah garis kemiskinan, dan melaksanakan delapan jạlurpemerataan yang meliputi pemerataan pembagian pendapatan, penyebaran pembangunan di segenap daerah, kesempatan memperoleh pendidikan, kesehatan, kesempatan kerja, berusaha, berpartisipasi dalam kegiatan pembangunan serta kesempatan memperoleh keadilan. Pada waktu itu disepakati bahwa programprogram pembangunan yang dilaksanakan 'bukan hanya mengejar kemajuan lahiriah seperti:' sandang, pangan, papan dan kesehatan, melainkan juga bagi memenuhi kepuasan batiniah seperti: pendidikan, rasa aman, bebas mengeluarkan pendapat, rasa keadilan. Bahkan pada waktu itu ditegaskan lagi bahwa hasil-hasil pembangunan hendaknya merata ke seluruh penjuru tanah air bukan hanya dinikmati oleh segolonganmasyarakat, tetapi dapat dirasakan oleh segenap anggota masyarakat.

Pemerintah kemudian 'semakin berperan aktif, terutama dengan menempatkan kedudukannya sebagai pelaksana kebijaksanaan ekonomi; sebagai konsumien, produsen sekaligus investor; sebagai pengelola perusahaan (negara); serta sebagai pengatur masyarakat (regulator). Sebagai pelaksana kebijaksanaan ekonomi, pemerintah secara aktif melakukan perubahan dan pembenahan masalah-masalah keuangan, perdagangan, perindustrian, dsb. Pemerataan dengan melalui lembaga-lembaga pasar, secara aktifmempengaruhi perjalanan serta proses penawaràn dan permintaan. Sebagai konsumen, pemerintah mendorongkegiatan yang bersentuhan langsung dengan barangbarang yang dikonsumsi. Hal serupa dilakukannya pula dalam kedudukannya 
sebagai produsen dan investor. Dalam konteks ini pemerintah tidak 'netral', tetapi mencampuri proses produksi. Sebagai pengelola perusahaan (negara), pemerintah secara aktif mempengaruhi pasar dan pemasaran disamping memberi stimulan tumbuh dan berkembangnya perusahaanperusahaan swasta. Akhirnya sebagai pengatur masyarakat (regulator), pemerintah menyusun perundangundangan yang memuat peraturan dan sangsi, sehingga derap pembangunan ekonomi berjalan berada pada jalur yang dikehendaki. Antuasisismemodemisasi dan rasionalisasi semacam itulah yang kelak semakin menempatkan pemerintah pada posisi amat sentral dalam kegiatan pembangunan ekonomi, serta cenderung mendominasi model perencanaan dan implementasi pembangunan.

\section{Dimensi Struktural Kemiskinan}

Upaya-upaya menanggulangi kemiskinan sampai saat ini masih dinilai belum berjalan sesuai dengan yang diharapkan. Kemiskinan belum berkurang dan isu-isu ketimpangan malah semakin deras mencuat di permukaan. Benar memang ada sejumlah pakar yang menyatakan bahwa apabila dibandingkan dengan keadaan beberapa negara di Asia, masyarakat kita sudah memasuki kategori moderate inequality artinya perbedaan tingkat kemakmuran antara berbagai golongan dalam masyarakát mulai mendekat. Tetapi dalam kenyataannya jumlah golongan miskin masih besar, bahkan terus membengkak. Mengapa demikian? Mengapa bermacam-macam program pembangunan ekonomi yang selama ini diçanangkan pemerintah tidak 'efektif? Mengapa bermacam-macam bantuan dikucurkan pemerintah tidak menyentuhkelompokmiskin? Tidakmudah menjawabpertanyaăn-pertanyaan semacam ini. Persoalan itu memaksakan kita untuk menelaah kembali dimensi struktural kemiskinan itu sendiri.

Secara sosiologis dimensi struktural kemiskinan itu dapat ditelusuri melalui institusional arrangements yang hidup dan berkembang dalam masyarakatkita. Asumsi dasarnya adalah bahwa kemiskinan tidak semata-mataberakarpada "kelemahan diri", yang lazim digambarkan secara individual ditandai sifat yang lazim disebut a strong feeling of marginality seperti: sikap parohial, apatisme, fatalisme atau pasrah pada nasib, boros, tergantung dan inferior dan secara kolektif hidup dalam keluarga yang ditandai free union or consensual marriages, serta tidak terintegritas secara efektif dengan institusi-institusi masyarakat. Kemiskinan dalam hal ini terutama sebagai konsekuensi dari pilihanpilihan strategi pembangunan ekonomi yang selama ini dicanangkan serta pengambilan posisi pemerintah dalam perencanaan dan implementasi pembangunan ekonomi itu sendiri.

Di pedesaan telah lama terjadi apa yang lazim disebut green revolution, yaitu suatu bentuk transformasi dahsyat dari sistem pertanian sederhana menjadi sistem pertanian modern. Transformasi itu dilakukan melalui intensifikasi, ektensifikasi dan komersialisasi pertanian untuk menghasilkan pangan yang sebesarbesarnya guna memenuhi kebutuhan nasional. Buahnya adalah telah mengangkat 
negarakita dari salah satunegara pengimpor beras nomer satu di dunia, menjadi negara berswasembada pangan. Keberhasilan ini disamping secara akademik telah menggugat kemapanan teori involusi pertarian, juga membuka mata dunia bagaimana negara ini telah mampu meningkatkan produksi padi secara besarbesaran dalam waktu yang relatif singkat.

Sebagai ilustrasi, kenaikan produksi padi di Jawa dari 1,81 ton per hektar menjadi 3,01 ton per hektar memakan waktu kurang dari 14 tahún. Sementara itu kenaikan produksi' pada di Jepang dari 2 ton per hektar menjadi 3,28 ton per hektar membutuhkan waktu kurang lebih 68 tahun (1880-1948) Di Taiwan, kenaikan dari 1,35 ton per hektar menjadi 3,1 ton per hektar. memerlukan waktu 57 tahun (1913-1970).

Tetapimengapa isu kemiskinan masih belum terpecahkan? Bukankah baik petani kaya maupun petani gurem memperoleh kesempatan yang sama dalam memanfaatkan fasilitas yang diintroduksi? Persoalannya memang tidak sederhana. Banyakstudimemperlihatkan bahwaproses introduksi itu temyata dibingkai oleh iklim ketidak-adilan. Banyak barang dan jasa terdistribusi mengikuti jalur kekuasaan; mereka yang berkuasa lebih banyak memonopoli barang dan jasa. Proses monopoli itu dapat dijelaskan melalui cycles sebagai berikut: Pertama berkaitan dengan akumulasi modal. Petani kaya memperoleh kesempatan lebih banyak mendapatkan aset-aset tambahan yang. datang bersamaan dengan teknologi pertanian 'modern. Mereka lebih cepat berkembang dibandingkan dengan petani miskin. Kedua, 'berkaitan dengan' fungsi lembaga-lembaga yang dibentuk untuk menunjang teknologi pertanian itu sendiri. Lembaga-lembaga itu dibentuk untuk mengakomodasi fụngsi produksi, struktur pasar serta preferensi, konsumen. Tetapi dalam kenyataannya hanya petani-petani kaya yang banyak menikmati jasa-jasa kelembagaan. Mereka adalah kelompokelit yang kerapkali sangat determinan dalam proses pengambilan keputusan-keputusan krusial.

Làlu bagaimana yang terjadi di perkotaan? Kondisinya hampir sama saja, meskipun déngan wajah yang agak berbeda. Para pengusaha yang memperoleh kucuran dana untuk menunjang proses industrialisasi, ternyata banyak. yang melakukan manipulasi dan monopoli. Dengan dalih efektivitas dan efisiensi mereka telah "merampas" tanah dan tenaga kerja yang murah dalam proses produksi. Ironisnya, beberapa kebijaksanaan justru memperlicin proses perampasan itu. Di samping itu' golongan menengah kota kita juga masih belum terbentuk, masih semu. Di dalam diri mereka belum terbentuk pandangan 'dan kepentingan politik yang terintegrasi bagi perkembangan ekonomi secara keseluruhan. Di dalam diri meréka belum tumbuh kesadaran kelas, karena itu mereka, memperoleh sebutan kelas menengah sebetulnya hanyalah dalam konsep longgar sehari-hari saja, bukan dalam konsep ideologi. Karena itu menjadi mudah dimengerti apabila kemudian sejumlah pakar dengan 'sinis menggolongkan mereka sebagai subelite yang feodalistik dan quasiliberal. Bahkan langkah-langkah yang mereka ambil kerapkali justru menutup akses kelompok miskin pada kegiatan perekonomian. 


\section{Sumberdaya Manusia}

Masalahlain yang berkait eratdengan kemiskinan adalah sindron inertia (lamban dan statis); sebagai akibat dari rendahnya kualitas sumberdaya manusia. Sebenarnya pemerintah telah berusaha membenahị dan menyusun berbagai macam kebijaksanaản pěndidikan yang diharapkạn dápatmemacu pengembangan sumberdaya manusia. Kebijaksanaan itu méncakup usaha peningkatan ketrampilan teknis melalui pendidikan kejuruan serta peningkatan keahlian (profesionalisme). Peningkatan itu antara lain dilakukan melalui pendekatan perluasan sarana serta mutu pendidikan dalam semua sektor, serta peningkatan produktivitas tenaga kerja. Tetapi sayangnya sekolah-sekolah'dan perguruanperguruan tinggi kita masih belum terjangkau oleh masyarakat umum. Jagad pendidikan kita masih kemasan barang luxury, terlảlu mewah. .

Perguruan-perguruan Tinggi Negeri hampir di seluruh penjuru tanah air, dalam beberapa tahun 'terakhir ini memang memperoleh kucuran anggaran yang lumayan besar. Kebutuhan-kebutuhan yang berkaitan dengan proses belajar-mengajar semakin diperbesar. Rasio dosen - manusia terus diusahakan diperkecil. Tetapi persoalannya siapa yang menikmatinya? Kelihatannya kebanyakan anak-anak dari "golongan menengah ke atas. Orang tua mampu membayar pendidikan ekstra di luarjam pelajaran sekolah. Karena itu tidak mengherankan apabila mereka lebih mampu mengerjakan ujian saringan yang masih dominan menggunakan test obyektif itu." Mereka yang gagal diterima di perguruan tinggi negeri kemudian berbondongbondong masuk ke perguruan tinggi swasta.
Biaya belajar perguruan tinggi swasta kini semakin mahal, terutama karena sebagian besardari anggaran pendidikandibebankan kepada mahasiswa. Di sinilah kerap kali terlihat pincang. Di satu pihak, mahasiswa dari keluarga kaya memperoleh subsidi pendidikan karena dapat diterima di perguruan tinggi negeri. Tetapi di lain pihak, mahasiswadari keluarga yañg relatif miskin harus membayar mahal (bahkan mungkin dieksploitasi) karena hanya diterima di. perguruan tinggi swasta.

Secara jujur harus diakui bahwa belum banyak jumlahnya perguruan tinggi kita baik negeri maupun swasta yang sudah mampumenghasilkan sarjana-sarjana yang mandiri dan secara profesional dapat menciptakan atau mengisi kesempatan kerja. Kualitas mereka banyak. belum memuaskan. Tidak mudah menerangkan mengapa kenyataan semacami ini masih terus terjadi. Masih banyak staf pengajar yang belum benar-benar memiliki kemampuan mengembangkan perspektif untuk menelaah ' masalah-masalah kemasyarakatan. Kurikulum yang ditawarkan juga belum mampu menjawab persoalan-persoalan yang muncul di lapangan. Demikian pula silabus yang dibuat belum terjabarkan dan belum menjawab tuntutan atau perkembangan keadaan. Unit-unit perpustakaanjuga belum termanfaatkan secara optimal. Semua kenyataan itu iclah menyulitkan proses peningkatan sumberdaya manusia yang handal.

\section{Program IDT}

Sejak pertemuan Kepala Negara dengan 14 Mcnteri Kabinel Pcmbangunan VI pada awal bulan April 1.993 yang lalu. 
pemerintah kembali menegaskan tekad menanggulangi kemiskinan. Realisasinya adalah mulai bulan April 1994 ini diluncurkan program Inpres Desa Tertinggal (Inpres No. 5/1993) pada sebanyak 20.633 desamiskin.Program IDT ini diharapkan menjadi gerakanmoral yang memberi kesempatan pada semua pihak, terutama penduduk miskin itu sendiri. Penduduk miskin yang tergabung dalam kelompok-kelompok swadaya masyarakat memperoleh dana $\mathrm{Rp} 20$ juta setiap desa berupa modal kerja untuk menggerakkan kegiatan perekonomian. Secara spesifik sasaran program ini adalah meningkatkan kesejahteraan sosial-ekonomi penduduk miskin melalui upaya peningkatan kualitas sumberdaya manusia, peningkatan kemampuan permodalan, pengembangan usaha dan pemantapan kelembagaan usaha bersama kelompok miskin tersebut; Pro: gram itu berjalan seiring dengan InpresInpres lain seperti: Inpres desa, kabupaten, provinsi, jalan, penghijauan, SD dan kesehatan.

Sejumlah kalangan tertentu merasa optimistik IDT bisa sukses. Sepanjang yang sudah berjalan, proyek-proyek pembangunan di bawah label Inpres relatif berjalan mulus sekalipun terdapat kebocoran. Proyek-proyek Inpres terlihat lebih rekat dengan pejabat baik daerah maupun pusat dibandingkan dengan proyek-proyek di luar Inpres. Seolah-olah kara "pres" (presiden) yang melekat dalam. nama proyek itu telah menjadi kata magis yang dapat memberi stimulan hebat. Tetapi sejumlah kalangan tertentu lainnya merasa pesimistik IDT bisa berhasil. Alasan yang disampaikan berkaitan dengan dimensi struktural kemiskinan seperti telah diuraikan di depan, antara lain: strategi pembangunan yang potensial bagi tumbuhsuburnya kolonialisme internal, kebijaksanaan yang membri peluang kelompok kaya memeraskelompok niskin, dan diskriminasi dalam pola peningkatan sumberdaya manusia. Bagi mereka penanggulangan kemiskinan bukan sematamata membagi bantuan uang kemudian melibatkan aparaturpemerintah, tetapi lebih daripada itu adalah keharusan menata kembali struktur sosial yang selama ini membelenggu kehidupankelompok miskin. Lalu bagaimana seharusnya sikapkita? Saya kira kita tidak perlu sinis terhadap IDT. Inpres ini sedang dalam tahap "uji coba" karena itu tentu butuh waktu bagi penyempurnaannya. Akạn lebih bijak menempatkan IDT sebagai salah satu program, dan bukan satu-satunya program. Dengan demikian semua pihak ditantang berkreasi menciptakan program-program penanggulangan kemiskinan yang lain.

\section{Daftar Bacaan}

'Alfian, Mely G. Tan dan Selo Şoemardjo (ed.), 1980, Kemiskinan Struktural, Suatu Bunga Rampai, Jakarta : Yayasan IlmuIlmu Sosial.

Bayliss-Smith, Tim P. and Sudhir Wanmali (ed), 1986, Understanding Green Revolutions, Cambridge : Cambridge University Press.

Jennett, Cristine and Randal G. Stewart (ed), 1987, Three Worlds of Inequality, Race, Class and Gender, Melboume : The MacMillan Company of Australia Pty Ltd.

Valentine, Charles A., 1970, Culture and Proverty, Critique and Counter-Proposals, Chicago: The University of Chicago Press.

Waxman, Chaiam I., 1977, The Stigma of Poverty, ACritique of Poverty Theories and Policies, New York : Pergamon Press. 